\title{
Synthesis, Characterisation and Analgesic Activity of Diethylenediamine Copper Complex
}

\author{
Kamel Mokhnache*, Ahlem Karbab, Soraya Madoui, Hanane Khither, El-Khamsa Soltani, Noureddine \\ Charef, Lekhmici Arrar
}

Laboratory of Applied Biochemistry, University Ferhat Abbas Setif 1, 19000, Algeria

\begin{abstract}
A new Copper-based compound was synthesized from coordination reaction of diethylenetriamine and copper ions, using copper chloride dehydrate in ethanol. This synthesized compound was characterized by a number of spectroscopic methods including UV, IR, and by elemental analysis. IR calculated vibration was carried out HyperChem 08 software, whereas analgesic activity was evaluated in vivo against acetic acid induced pain in mice model. Results obtained from theoretical and experimental investigations demonstrate the high analgesic effect of copper complex towards acetic acid with percentages of 85.39 and $89.68 \%$ respectively, which is comparable with that of aspirin and tramadol (18.9 and $79.78 \%$ respectively).
\end{abstract}

Keywords: Copper complex, Synthesis, Analgesic, Prediction.

Article Info: Received 08 Sep 2019; $\quad$ Review Completed 13 Oct 2019; $\quad$ Accepted 20 Oct 2019; Available online 15 Nov 2019

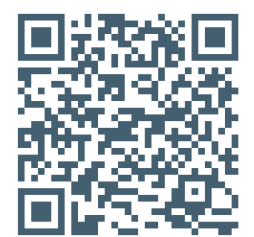

Cite this article as:

Mokhnache K, Karbab A, Madoui S, Khither H, Soltani E, Charef N, Arrar L, Synthesis, Characterisation and Analgesic Activity of Diethylenediamine Copper Complex , Journal of Drug Delivery and Therapeutics. 2019; 9(6):51-54 http://dx.doi.org/10.22270/jddt.v9i6.3665

Kamel Mokhnache*, Laboratory of Applied Biochemistry, University Ferhat Abbas Setif 1, 19000, Algeria

\section{INTRODUCTION}

Pain is defined as an unpleasant sensory and emotional experience associated with actual or potential tissue injury. Painful transmission is a complex phenomenon involving electrophysiological and neurochemical mechanisms [1].Traumatic, inflammatory or ischemic lesions cause the release of damaged chemicals. These substances can either directly activate the nociceptors (bradykinins, potassium ions, hydrogen, nitric oxide, histamine and serotonin) or sensitize the nociceptors to other stimuli. In addition, Prostaglandins and leukotrienes, play a role of sensitizers of nociceptors acting on other substances such as the peptides involved in the transmission of the pain message. Substance $P$ is best known as a neuropeptide (neurotransmitter) and plays a primordial role in nociception and has a vasodilatory action at the origin of algogenic inflammation [2]. An analgesic is a drug used in the fight against pain. Generally, analgesic drugs are associated with various undesirable gastrointestinal effects [3]. From these reasons, there is the need for the search of new safe analgesics.

In this study, Copper-based compound was predicted for their analgesic activity using the web tool PASS online, then synthesized, characterized and investigated in vivo for their analgesic effect using acetic acid intraperetenialy injection in mice model. This complex was synthesized from the coordination reaction of copper (II) chloride dehydrate and diethylenetriamine in ethanolic solution.

\section{MATERIALS AND METHODS}

\section{MATERIALS}

The chemicals was purchased and used without further purification: diethylenetriamine, copper chloride dehydrate (Sigma-Aldrich), Acetic acid (Merck). Infrared spectra (IR) were obtained, as $\mathrm{KBr}$ disks, on a Schimadzu FTIR-8400S spectrophotometer. The electronic absorption spectra in the 200-900 $\mathrm{nm}$ range were recorded on a UV-1800Schimadzu UV-visible spectrophotometer. Elemental analysis (C, H, and N) was carried out with a EuroVector EA3000 instrument.

\section{Synthesis of diethylenediamine copper complex}

Ethanolic solution of $\mathrm{CuCl}_{2.2} \mathrm{H}_{2} \mathrm{O}(0.01 \mathrm{~mol}, 1.0748 \mathrm{~g})$ was added to diethylenetriamine $(0.01 \mathrm{~mol}, 1.0317 \mathrm{~g})$, the mixture was refluxed for $1 \mathrm{~h}$ at $78^{\circ} \mathrm{C}$. After cooling, the precipitate solid was filtered, isolated and washed several time with ethanol (Scheme 1). 


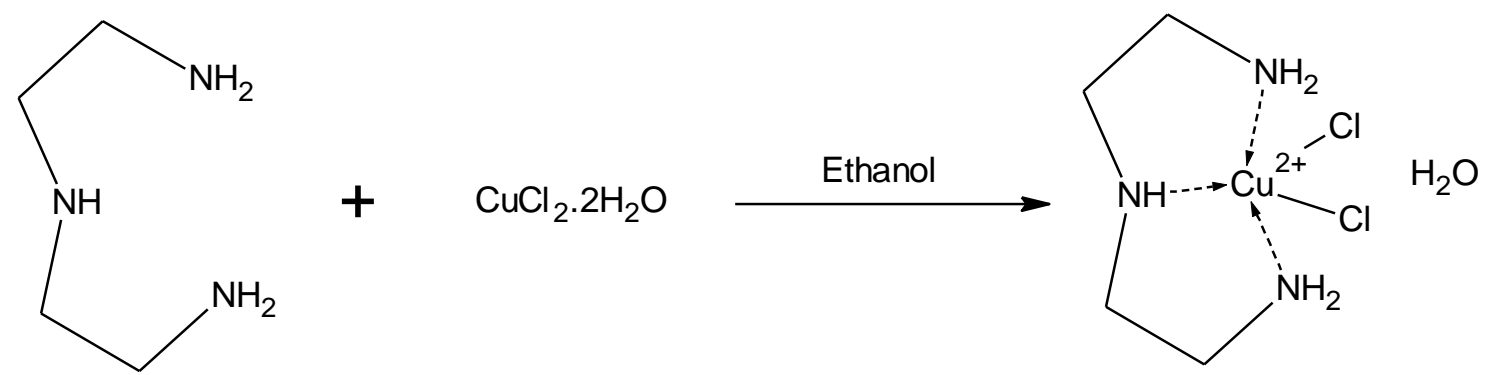

Scheme 1. Synthesis of copper complex

Yield 86\%. UV-Vis $\left(\mathrm{H}_{2} \mathrm{O}\right) \lambda_{\max }(\mathrm{nm})$ 247. IR (KBr, cm-1): $\nu_{\max }$ 3276-3243 (br, $\mathrm{NH}_{2}$ ), Anal. Calcd for $\mathrm{C}_{4} \mathrm{H}_{15} \mathrm{Cl}_{2} \mathrm{CuN}_{3} \mathrm{O}: \mathrm{C}, 18.79 ; \mathrm{H}_{\text {, }}$ 5.91; N, 16.44. Found: C, 19.52; H, 5.59; N, 16.83\%.

\section{Theoretical vibration data prediction}

Calculated vibration was carried out HyperChem 08 software, with molecular mechanic force field (MM+) and semi-empirical AM1, PM3 methods [4].

\section{In silico analgesic activity prediction}

The web tool PASS online was employed for analgesic activity predictions, in which the obtained values are the results of the difference between the probability of molecular activity and inactivity values [5].

\section{In vivo analgesic activity evaluation}

In this assay, female mice were employed, divided into five groups of five animals each $(n=5)$. These mice were subjected to fasting for $12 \mathrm{~h}$ before the experiment but allowed free access to water except during the experiment. Mice were intra-peritoneally injected with $0.1 \%$ (v/v) acetic acid to induce writhes after 60 minutes of oral treatment with water as a vehicle, Copper complex ( 5 and $10 \mathrm{mg} / \mathrm{kg}$ ) or aspirin $(100 \mathrm{mg} / \mathrm{kg})$ as a positive control. Number of abdominal constrictions was counted over a period of 30 minutes by an observer unaware of the treatment after 5 minutes of injection. The percentage inhibition of writhing reflex was calculated using the formula: \% inhibition $($ protection $)=100 \times(\mathrm{Nc}-\mathrm{Nt}) / \mathrm{Nc}$, where $\mathrm{Nc}=$ mean number of writhes in control $\mathrm{Nt}=$ mean number of writhes in test [6].

\section{RESULTS AND DISCUSSION}

\section{Chemistry}

Copper complex was prepared from the reaction between copper chloride dehydrate and diethylenetriamine.

The infrared spectra of the synthesized complex indicate the presence of the amine group $\left(\mathrm{NH}_{2}\right)$ at $3276-3243 \mathrm{~cm}^{-1}$. Also, the appearance of new bands between 500 and $600 \mathrm{~cm}^{-1}$ is due to the coordination of copper ions with nitrogen of the amine. This confirms that the synthesis of the complex has taken place (Fig 1).

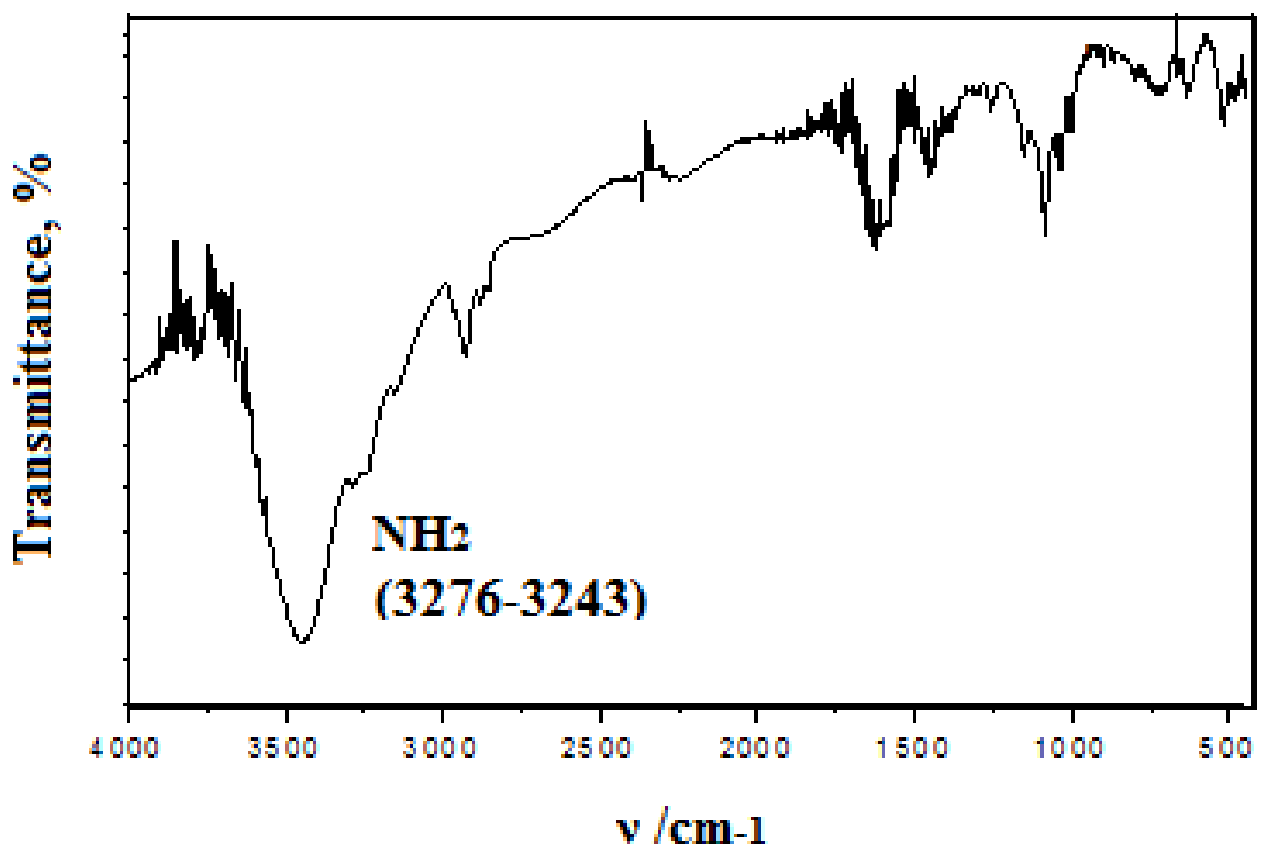

Fig 1: FT-IR spectrum of Copper complex

In addition, experimental analysis data are in perfect agreement with the theritical data of this compound.

Furthermore, an excellent correlation was obtained between experimental and calculated IR vibration in the both methods, AM1 and PM3, with correlation coefficient values of 0.998 and 0.991 for the synthesized complex (Fig 2). 

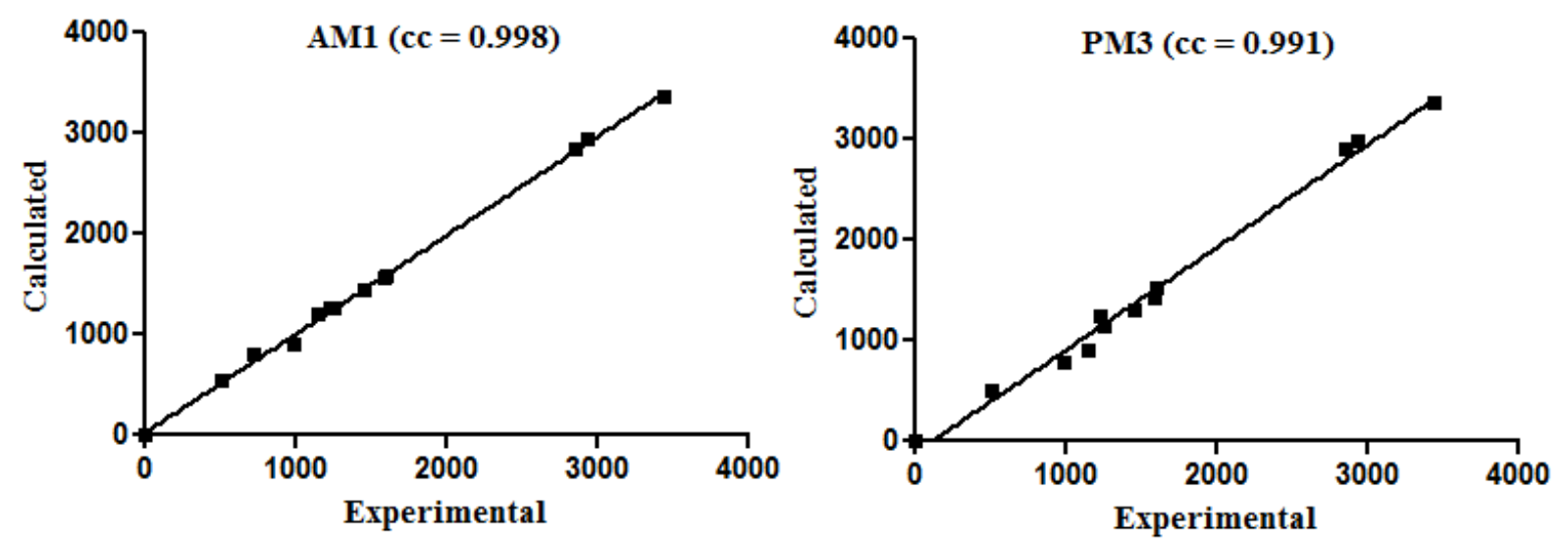

Fig 2: Graphical correlations between the experimental and calculated IR vibration of Complex obtained by AM1 and PM3 semiempirical methods (cc = correlation coefficient).

\section{In silico analgesic activity prediction}

Pain is one of the most important health problems because of its prevalence and the disability it can cause. Chronic pain may be the result of inflammatory diseases or tissue damage such as nerve damage in the case of neuropathic pain. In Europe, chronic pain affects about 17 to $45 \%$ of the population [7]. In addition, chronic pain is often resistant to existing therapy; for this reason, there is a great need for new drug research [8]. In recent years, computational methods were used as a first step for drug discovery and development. This approaches, have an exclusive advantage of being able to evaluate the biological effect of drugcandidate substances before they are synthesized. According to these efficient approaches, the synthesized copper complex was investigated in silico for their analgesic activity. The predicted results (Fig 3) demonstrate that the synthesized copper complex exhibit an excellent analgesic effect with probability of $85.39 \%$, followed with the opioid drug; Tramadol with $83.83 \%$ and no-opioid drug; aspirin with $18.9 \%$. From these results, the synthesized copper complex has a similar effect of the opioid drug; Tramadol which exhibit their spinal analgesic effect via $\mu 2, \kappa 1, \delta 2$ receptors [9].

\section{Analgesic activity Prediction}

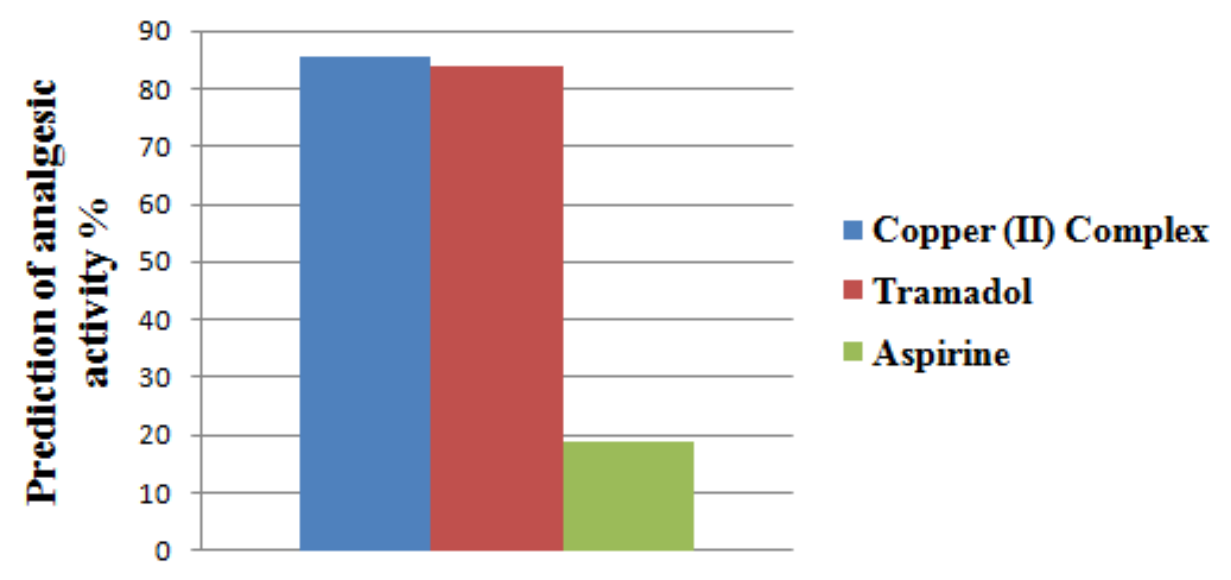

Fig 3: In silico prediction of analgesic potential of Copper complex, Tramadol and Aspirin

\section{In vivo analgesic activity evaluation}

The intraperitoneal injection of acetic acid in mice causes a pain syndrome that results in characteristic writhing type of stretching movement of the hind legs and the dorso-ventral musculature. These events are strongly related to the sensitization of the nociceptive receptors that will induce the synthesis of PGE2, PGF2 $\alpha$, serotonin and histamine [10]. This assay has the great interest in analgesic drugs screening [11]. The analgesic substances cause the decrease in these contortions. In this study, the obtained results presented in Fig 4 show that the administration of 10 and $5 \mathrm{mg} / \mathrm{kg}$ of the synthesized copper complex and $100 \mathrm{mg} / \mathrm{kg}$ of aspirin exerted a protective effect against the pain caused by the acetic acid. The potent inhibitory effect of abdominal contractions is recorded at the doses of 10 and $5 \mathrm{mg} / \mathrm{kg}$, which exhibited an inhibitory effect of 89.68 and $76.07 \%$ respectively. These effects are better than that of $100 \mathrm{mg} / \mathrm{kg}$ aspirin $(79.78 \%)$. In literature, several sutdies demostrate that copper represents an oligoelement with high analgesic activities [12]. Also, demonstare that copper complexes of anti-inflammatory enchanced analgesic effect of these drugs. In conclusion, the experimental results are in good correlation with theoretical results. From these results, the synthesized copper complex could be an analgesic candidate drug, which proposed act on the peripheral and central nervous systems. 


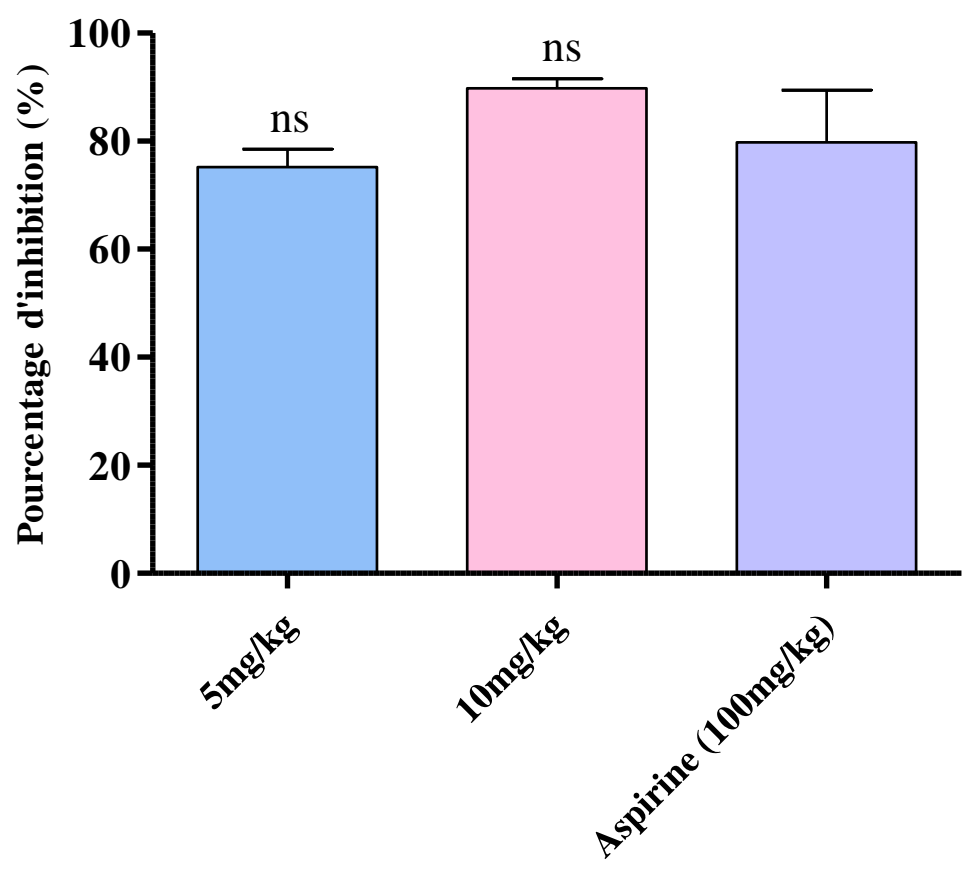

Fig 4: Analgesic activity of Copper complex (5 and $10 \mathrm{mg} / \mathrm{kg}$ ) and aspirin (100 mg/kg)

\section{CONCLUSIONS}

We conclude that the synthesized copper complex could be an analgesic candidate drug, which proposed act on the peripheral and central nervous systems.

\section{REFERENCES}

[1] IASP, International Association for the Study of Pain: Pain Definitions" available on http://www.iasppain.org/taxonomy, 2015. Retrieved 26 November 2015.

[2] Rabaud C, Rogeaux O, Launay O, Strady C, Mann C, Chassany O, Bouhassira D, Gaillat J. Early antiviral treatment fails to completely prevent herpes-related pain. Médecine et maladies infectieuses. 2013; 43: 461-466.

[3 ]Mate GS, Naikwade NS, Chowki CSA, Patil SB. Evaluation of Anti-nociceptive Activity of Cissus quadrangularis on Albino Mice. Int J Green Pharm. 2008; 2:118-121.

[4] Mokhnache K, Madoui S, Charef N. Quantum Chemical Calculation, Hemolytic Effect and Anti-Denaturation Activity of Schiff Base Ligand. International Journal of Scientific Engineering and Science. 2019; 5: 27-29

[5] Casas KGO, Oliveira MLG, de Fátima Silv GD, Viasus CJ, Burgos AE. Synthesis of $\mathrm{Cu}(\mathrm{II})$ complex with schiff bases derived from aryl-S-benzyildithiocarbazate: Antimicrobial activity and in silico biological properties evaluations. African Journal of Pharmacy and Pharmacology. 2015; 9:1009-1019
[6] Ishola IO, .Akindele AJ, Adeyenni OO. Analgesic and antiinflammatory activities of Cnestisferruginea Vahk ex DC (Conmaraceae) methanolic root extract. Journal of Ethnopharmacology. 2011; 135 : 55-62.

[7] Elliott AM, Smith BH, Hannaford PC, Smith WC, Chambers W. (2002). " The cours of chronic pain in the community: results of a 4-year follow-up study pain»; Vol 99; pp: 299307.

[8] Wang LX, Wang ZJ. «Animal and cellular models of chronic pain»; Advanced drug Delivery Reviews. 2003; 55: 949-965.

[9] Arslan R, Bektas N, Ozturk Y. Anti-nociceptive activity of methanol extracts of fruits of Capparisovata in mice. Journal of Ethnopharmacology.2010; 131: 28-32.

[11] Soro TH, Traore F, Sakande J. Activité analgésique de l'extrait aqueux de Ximenia americana (Linné) (Olacaceae). C R Biol.2009; 332: 371-377.

[11]Hasan SMR, Hossain MM, Akter R, Jamila M, Mazumder MEH, Alam MA, Faruque A, Rana S, Rahman S. Analgesic activity of the different fractions of the aerial parts of Commelina benghalensis Linn. International Journal of Pharmacology. 2010; 6 : 63-67.

[12] Sorenson JR. Copper complexes offer a physiological approach to treatment of chronic diseases. Progress in Medicinal Chemistry.1989; 26:437-568 